\section{Evaluation of serum 25-hydroxy vitamin D3 levels in goat kids naturally infected with Giardia duodenalis}

\section{Giardia duodenalis ile doğal enfekte oğlaklarda serum 25- hidroksi vitamin $D_{3}$ düzeylerinin değerlendirilmesi}

\begin{abstract}
The aim of this study was to determine 25-hydroxy vitamin $\mathrm{D}_{3}$ levels in diarrhoeic goat kids. For this purpose, blood sample witdrawn from 10 diarrhoeic goat kids (Group I) and 10 healthy goat kids (Group II). Diagnosis of giardiasis was performed with multiple methods including microscopic examination and rapid test kits. Mean 25hydroxy vitamin $\mathrm{D}_{3}$ levels were determined as $33,37 \mathrm{ng} / \mathrm{mL}$ in diarrhoeic goat kids and $86,78 \mathrm{ng} / \mathrm{mL}$ in control and that is found to statistically significant $(\mathrm{p}<0.001)$. Consequently, it was convinced that giardiasis-related intestinal malabsorption may cause severe reduction in vitamin D levels and vitamin D supplement should be administered proper and sufficient doses due to anti-microbial effect with anti-giardial medication in treatment regime.
\end{abstract}

Keywords: Goat, vitamin D, deficiency, giardiasis

\section{ÖZET}

$\mathrm{Bu}$ çalışmada ishalli oğlaklarda 25-hidroksi vitamin $\mathrm{D}_{3}$ seviyelerinin belirlenmesi amaçlandı. Bu amaçla 10 ishalli (grup I) ve 10 sağlıklı (grup II) oğlaktan kan örnekleri topland1. Giardiazisin tanısında mikroskobik muayene ve hizlı tanı test kitlerinden yararlanıld. Ortalama 25-hidroksi vitamin $\mathrm{D}_{3}$ seviyeleri ishalli grupta $33,37 \mathrm{ng} / \mathrm{mL}$ iken sağlıklılarda $86,78 \mathrm{ng} / \mathrm{mL}$ olarak ölçüldü ve bu farklılık istatistiksel olarak anlamlı bulundu $(\mathrm{p}<0.001)$. Sonuç olarak giardiazis ilişkili intestinal malabsorbsiyonların D vitamin seviyesinde şiddetli azalmalara neden olabileceği ve anti-giardiyal sağaltım yanında antimikrobiyel etkilerinden dolayı vitamin D takviyelerinin uygun ve yeterli dozda sağaltım rejimlerine eklenmesi gerektiği kanaati oluştu.

Anahtar Kelimeler: Keçi, vitamin D, yetmezlik, giardiazis

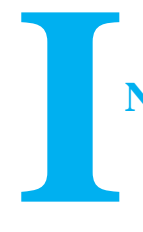

\section{NTRODUCTION}

Especially suitable geographical conditions for goat breeding increases the rearing and spreading of this species in Turkey (Günlü and Alaşahan, 2010). On the other hand, improper hygiene standards may result within the interaction of some zoonotic disease between humans and animals (Matilla et al., 2018) as like giardiasis. Several forms of Giardia duodenalis involving seven assemblages (AG) and assemblage E zoonotic for small ruminant (Jafari et al., 2014) have been implicated. Its zoonotic potential creates danger for human especially in child (Al-Habsi et al., 2017; Horton et al., 2019).

\section{How to cite this article}

Erdogan, S., Ural, DA., Erdogan H., Ayan, A., Ural, K., Ozalp, T., Gunal, I. (2020). Evaluation of serum 25-hydroxy vitamin D3 levels in goat kids naturally infected with Giardia duodenalis Journal of Advances in VetBio Science and Techniques. 5(2): 43-47. https://doi.org/10.31797/vetbio.696080
Research Article

$$
\begin{array}{r}
\text { Songül Erdoğan }^{1 \mathrm{a}} \\
\text { Deniz Alıç Ural }^{2 \mathrm{~b}} \\
\text { Hasan Erdoğan }^{1 \mathrm{c}} \\
\text { Adnan Ayan }^{3 \mathrm{~d}} \\
\text { Kerem Ural }^{1 \mathrm{e}} \\
\text { Tahir Özalp }^{1 \mathrm{f}} \\
\text { İsmail Günal }^{4 \mathrm{~g}}
\end{array}
$$

${ }^{1}$ Veterinary Faculty of Aydın Adnan Menderes University, Department of Internal Medicine, Aydin, Turkey

${ }^{2}$ Veterinary Faculty of Aydin Adnan Menderes University, Animal Farm, Aydın, Turkey

${ }^{3}$ Veterinary Faculty of Van Yüzüncü Y1l University, Department of Genetics, Van, Turkey

${ }^{4}$ Harran University, Veterinary Faculty, Internal Medicine, TR63000 Şanlıurfa - Turkey

ORCID${ }^{\mathrm{a}} 0000-0002-7833-5519$ b0000-0002-2659-3495 c0000-0001-8109-8537 d0000-0002-6564-3416 e0000-0003-1867-7143 f $0000-0002-9873-0364$ g 0000-0003-3679-4132

Correspondence Songül ERDOĞAN Araş. Gör. Dr. İç Hastalıkları songultp.09@gmail.com

Article info

Submission: 28-02-2020

Accepted: 05-08-2020

Online First: 08-08-2020

e-ISSN: 2548-1150

doi prefix: $10.31797 /$ vetbio - http://dergipark.org.tr/vetbio

This work is licensed under a Creative Commons Attribution 4.0 International License (c) (i) 
Giardiasis is caused by Giardia spp. commonly $G$. duodenalis as a protozoan flagellate agent and it might infect multiple hosts that have a wide range of organism including mammals, birds and amphibians. Furthermore, giardiasis has a common prevelance in goat kids as like other ruminant (Santin et al., 2007: Geurden et al., 2008; Squire et al., 2017; Santin, 2020). Diarrhoea, weight loss and mortalities might be occured in goat kids (O'Handley and Olsen, 2006). In this contex enteric parasite G. duodenalis causes growth retardation related to diarrhea in young animal unlike adults, of which disease especially possess subclinical process (Lalle et al., 2005; O'Handley and Olson, 2006; Ural et al., 2017).

Vitamin D synthesis exist through two ways including skin in that cholecalciferol as also known Vitamin $\mathrm{D}_{3}$ formed by photolyzes of epidermal 7-dehydrocholesterol with absorbed ultraviolet light and ergocalciferol as known Vitamin $\mathrm{D}_{2}$ proceed from a dietary steroid. After transferred into circulation, both compounds are hydroxylated to 25hydroxyvitamin D and 1,25-dihydroxyvitamin $\mathrm{D}$ that is active metabolite of vitamin $\mathrm{D}$ in liver and kidney via consecutively enzymatic reaction (MacLaughlin et al., 1982; Webb and Holick, 1988). Vitamin D is synthesised in both humans and ruminant skin (Holick et al., 1979; Hymøller and Jensen, 2010), contrary to dog and cats only required with diet (How et al., 1994). Like large and small ruminants can be able to produce Vitamin D by mostly their skin and nutritional way (Hidiroglou and Karpinski, 1989; Kovács et al., 2015; Nemeth et al., 2017).

According to this study authors, giardiasis one of the most common and unminded aetiological agents of diarrhoeic young small ruminant. Commonly distribution and molecular characterization of agent has been researched in many studies (Santin et al., 2007; Geurden et al., 2008; Jafari et al., 2014; AlHabsi et al., 2017; Squire et al, 2017; Horton et al., 2019; Santin, 2020). Indeed, vitamin D levels in goat kids infected with giardia was questioned. For this purpose, we aimed to determine 25- hidroxy vitamin $\mathrm{D}_{3}$ levels in diarrhoeic goat kids.

\section{MATERIALS AND METHODS}

The animal of the study was formed within 10 diarrhoeic goat kids (Group I) and 10 healthy goat kids (Group II) from commercial goat farm located in Aydin province. Both groups were selected from different gender and 15-35-day old age.

Diagnosis of giardiasis consisted of both the microscopic examination of Giardia cysts/trophozoites and rapid test kits (Anigen Rapid Bovid-5 Ag Test Kit, Bionote Lab.) principled with ELISA used to determine the antigen of the parasite ( 125 cysts and above in $100 \mu \mathrm{L}$ feces) (Olson et al., 2010) in fecal samples collected rectally. Additionally, fecal samples collected from the healthy group with no symptoms of diarrhea were subjected to similar procedures with Group I for detecting negative status of giardiasis.

Blood samples were withdrawn from Vena jugularis to serum tubes (BD Vacutainer ${ }^{\circledR}$ Plus Serum Tüpleri, Becton, Dickinson and Company, New Jersey, ABD) for once were centrifuged at $3000 \mathrm{RPM}$ for $10 \mathrm{~min}$ and separated serum. Following this process, serum 25- hidroxy vitamin $\mathrm{D}_{3}$ levels were measured by commercial test kits working with immune fluorescence method (Beijing Savant Biotechnology Co., China). After completed of study, standard anti-giardial treatment protocol was applied to Group I.

Obtained data were evaluated whether the descriptive statistics showed normal distribution. Differences between the groups were determined with Mann-Whitney U test. All analysis was realized with SPSS programme (SPSS 22.0, IBM) and $p<0.05$ were considered statistically significant. 


\section{Ethical statement}

This study was approved by local ethics committee of Aydin Adnan Menderes University with number of 2013/076.

\section{RESULTS}

Diarrhoeic all goat kids were found to be infected with $G$. duodenalis as a result of fecal microscopic examination and rapid test (Figure 1). Additionally, weight loss was seen in all diarrhoeic animals. There were no clinical findings were observed except weight loss and diarrhea. The main body tempature, respiratory rate and heart rate were $39.2^{\circ} \mathrm{C}, 38$ breats per minute, 82 beats per minute, respectively.

There were statistically significant results related to 25-hidroxy vitamin $\mathrm{D}_{3}$ levels of healthy (Group II) and infected goat kids (Group I) (Table 1).

Tablo 1. Mean 25-hidroxy vitamin $\mathrm{D}_{3}$ levels in goat kids.

\begin{tabular}{lccc}
\hline & n & X \pm SD & p value \\
\hline Healthy (Group I) goat kids & 10 & $86,78 \pm 21,30^{\mathrm{a}} \mathrm{ng} / \mathrm{mL}$ & \\
Infected (Group II) goat kids & 10 & $33,37 \pm 16,31^{\mathrm{b}} \mathrm{ng} / \mathrm{mL}$ & $\mathrm{p}<0.001$ \\
\hline${ }^{\mathrm{a}, \mathrm{b}}$ : Values within a column with different superscripts are statistically different ( $\left.<<0.05\right)$.
\end{tabular}

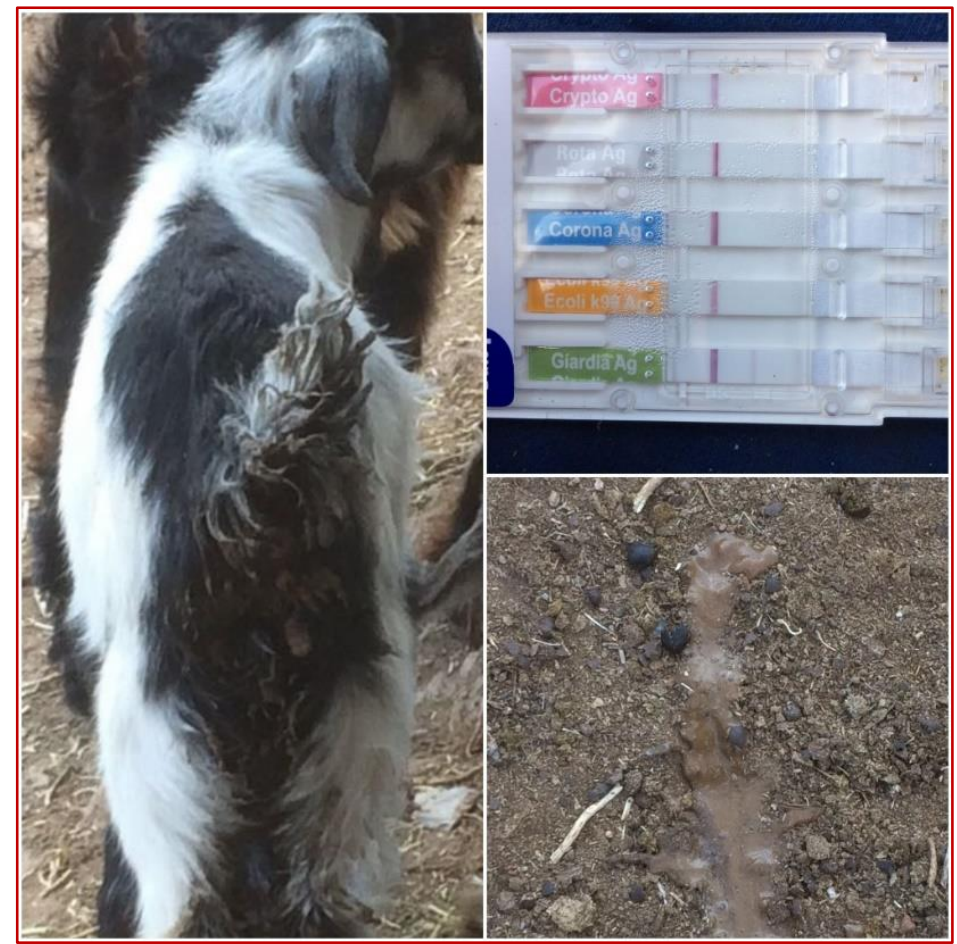

Figure 1. Diarrhoetic goat kids infected with $G$. duodenalis diagnosed by rapid test kits.

\section{DISCUSSION}

Giardiasis in small ruminant has generally unminded aetiological agents for subclinical diarrhea process and related study has mostly about its molecular characterization. On the other hand, vitamin D levels involved in many physiological functions was questioned in infected goat kids. For this purpose, we aimed 
to determine 25-hidroxy vitamin $\mathrm{D}_{3}$ levels in diarrhoeic goat kids.

Decreased appetite, fecal formation and mild depression were observed in the seventh-eighth days after post inoculation in goat kids experimentally infected with giardiasis $\left(3 \times 10^{6}\right.$ giardia inoculated). The same study was found to goat kids were abnormally defecation over an average six-day period (Koudela and Vitovec, 1998). Our study realized in naturally infected animals under field conditions was determined that goat kids were not depressed even though decreased appetite and deterioration in fecal formation. It was stated that feces formation was soften for more than five days according to goat keepers' anamnesis.

The study performed in northern India reported that the prevalence of $\mathrm{G}$. duodenalis was $33.8 \%$ in goats close contact with humans. And also it was stated that zoonotic assemblages A and B was predominant in the same study unlike others declared of nonzoonotic assemblage $\mathrm{E}$ in goats (Utaaker et al., 2017). Analyzed of related study, it is seen that farm keeper, veterinarians and relevant stakeholders are at risk. In our study, it was recommended to taking preventive measures under the control of both farm keepers and related stakeholders.

As interestingly phrynoderma rarely seen pattern of follicular hyperkeratosis in 6-year-old boy attributed with chronic giardisis takes an important place in literatures. It was associated with vitamin deficiency (A and C) and essential fatty acids. In the same study was stated that vitamin deficiency occured by intestinal malabsorption as a result of this chronic parasiter intestinal infection (Girard et al., 2006). It was thought that vitamin $D$ deficiency may be associated with malabsorption due to chronic giardiasis although it has not been proven clearly based on the similar hypothesis. Similarly, one of the results of diarrhea was reported to accompany vitamin D deficiency in human medicine (Abed et al., 2014). In a recent study including some of the authors, vitamin D levels of diarrhoeic lambs infected with $G$. duodenalis, were found to be lower than healthy ones (Camkerten et al., 2019). Indeed, mentioned hypothesis of Girard et al. (2006) is supported by our results that mean vitamin D levels were determined as $33,37 \mathrm{ng} / \mathrm{mL}$ in diarrhoetic goat kids and $86,78 \mathrm{ng} / \mathrm{mL}$ in control as like our previous study (Camkerten et al., 2019) in lambs.

\section{CONCLUSION}

Consequently, it was convinced that giardiasisrelated intestinal malabsorption may cause severe reduction in vitamin $\mathrm{D}$ levels and vitamin D supplement should be administered proper and sufficient doses with anti-giardial medication in treatment regime.

\section{REFERENCES}

Abed, N.T., Mohamed NS, Abdel-Gawad ER, \& Ibrahim SG. (2014). Vitamin D status in children with recurrent acute diarrhea. International Journal of Current Microbiology and Applied Sciences, 3:85868.

Al-Habsi, K., Yang, R., Williams, A., Miller, D., Ryan, U., \& Jacobson, C. (2017). Zoonotic Cryptosporidium and Giardia shedding by captured rangeland goats. Veterinary Parasitology: Regional Studies and Reports, 7:32-35.

Camkerten, G., Erdoğan, H., Ural, D.A., Camkerten, I., Erdoğan, S., \& Ural, K. (2019). Giardia duodenalis ile Doğal Enfekte Kuzularda Serum 25 (OH) D3 Seviyeleri. Kocatepe Veterinary Journal, 12(1):71-4.

Geurden, T., Thomas, P., Casaert, S., Vercruysse, J., \& Claerebout, E. (2008). Prevalence and molecular characterisation of Cryptosporidium and Giardia in lambs and goat kids in Belgium. Veterinary Parasitology, 155(1-2):142-145.

Girard, C., Dereure, O., Blatière, V., Guillot, B., \& Bessis, D. (2006). Vitamin A deficiency phrynoderma associated with chronic giardiasis. Clinical Pediatric Dermatology, 23(4):346-9.

Günlü, A., \& Alaşahan, S. (2010). Türkiye'de keçi yetiştiriciliği ve geleceği üzerine bazı değerlendirmeler. Veteriner Hekimler Derneğ $i$ Dergisi, 81(2):15-20. 
Hidiroglou, M., \& Karpinski, K. (1989). Providing vitamin D to confined sheep by oral supplementation vs ultraviolet irradiation. Journal of Animal Science, 67(3):794-802.

Holick, M. F., Richtand, N. M., McNeill, S. C., Holick, S. A., Frommer, J. E., Henley, J. W., \& Potts Jr, J. T. (1979). Isolation and identification of previtamin D3 from the skin of rats exposed to ultraviolet irradiation. Biochemistry, 18(6):1003-1008.

Horton, B., Bridle, H., Alexander, C. L., \& Katzer, F. (2019). Giardia duodenalis in the UK: current knowledge of risk factors and public health implications. Parasitology, 146(4):413-424.

How, K. L., Hazewinkel, H. A. W., \& Mol, J. A. (1994). Dietary vitamin D dependence of cat and dog due to inadequate cutaneous synthesis of vitamin D. General and Comparative Endocrinology, 96(1):1218.

Hymøller, L., \& Jensen, S. K. (2010). Vitamin D3 synthesis in the entire skin surface of dairy cows despite hair coverage. Journal of Dairy Science, 93(5):2025-2029.

Jafari, H., Jalali, M., Shapouri, M., \& Hajikolaii, M. (2014). Determination of Giardia duodenalis genotypes in sheep and goat from Iran. Journal of Parasitic Diseases, 38(1):81-84.

Koudela, B., \& Vítovec, J. (1998). Experimental giardiasis in goat kids. Veterinary Parasitology, 74(1):9-18.

Kovács, S., Wilkens, M., \& Liesegang, A. (2015). Influence of UVB exposure on the vitamin D status and calcium homoeostasis of growing sheep and goats. Journal of Animal Physiology and Animal Nutrition, 99: 1-12.

Lalle, M., Pozio, E., Capelli, G., Bruschi, F., Crotti, D., \& Caccio, S. M. (2005). Genetic heterogeneity at the $\beta$-giardin locus among human and animal isolates of Giardia duodenalis and identification of potentially zoonotic subgenotypes. International journal for parasitology, 35(2):207-213.

MacLaughlin, J. A., Anderson, R. R., \& Holick, M. F. (1982). Spectral character of sunlight modulates photosynthesis of previtamin D3 and its photoisomers in human skin. Science, 216(4549):1001-1003.

Matilla, F., Velleman, Y., Harrison, W., \& Nevel, M. (2018). Animal influence on water, sanitation and hygiene measures for zoonosis control at the household level: A systematic literature review. PLoS Neglected Tropical Diseases, 12(7):e0006619.

Nemeth, M. V., Wilkens, M. R., \& Liesegang, A. (2017). Vitamin D status in growing dairy goats and sheep: Influence of ultraviolet B radiation on bone metabolism and calcium homeostasis. Journal of Dairy Science, 100(10):8072-8086.

O'Handley, R. M., \& Olson, M. E. (2006). Giardiasis and cryptosporidiosis in ruminants. Veterinary Clinics: Food Animal Practice, 22(3):623-643.
Olson, M. E., Leonard, N. J., \& Strout, J. (2010). Prevalence and diagnosis of Giardia infection in dogs and cats using a fecal antigen test and fecal smear. The Canadian Veterinary Journal, 51(6):640.

Santin, M. (2020). Cryptosporidium and Giardia in Ruminants. Veterinary Clinics: Food Animal Practice, 36(1):223-238.

Santín, M., Trout, J. M., \& Fayer, R. (2007). Prevalence and molecular characterization of Cryptosporidium and Giardia species and genotypes in sheep in Maryland. Veterinary Parasitology, 146(1-2):17-24.

Squire, S. A., Yang, R., Robertson, I., Ayi, I., \& Ryan, U. (2017). Molecular characterization of Cryptosporidium and Giardia in farmers and their ruminant livestock from the Coastal Savannah zone of Ghana. Infection, Genetics and Evolution, 55:236243.

Ural, D. A., Erdoğan, H., Toplu, S., \& Ayan, A. (2017). Oğlaklarda Giardiazis Kontrolüne Yönelik Oral Klinoptilolit Uygulaması. Kocatepe Veterinary Journal, 10(3):158-163.

Utaaker, K. S., Myhr, N., Bajwa, R. S., Joshi, H., Kumar, A., \& Robertson, L. J. (2017). Goats in the city: prevalence of Giardia duodenalis and Cryptosporidium spp. in extensively reared goats in northern India. Acta veterinaria scandinavica, 59(1):86.

Webb, A. R., \& Holick, M. F. (1988). The role of sunlight in the cutaneous production of vitamin D3. Annual Review of Nutrition, 8(1):375-399. 